\title{
FOLLOW THE MATERIAL! FOLGE DEM MATERIAL!
}

$\nearrow$ HÉLÈNE FRICHOT // German translation: Christa Wendl, Lukas Allner and Daniela Kröhnert

There is a telling scene in the American TV series The Wire in which a wise old newcomer to a team of police investigators painstakingly explains to the group that to get to the bottom of the Baltimore drug ring they will have to "follow the money!" He explains to his colleagues, whose attempts to break up a debilitating local trade in drugs have mostly been thwarted, that if "you follow the drugs, you get drug addicts and drug dealers, but you start to follow the money, and you don't know where the fuck it's gonna take you...". This reorientation of their efforts turns out to be a breakthrough for the team. They will, in time, discover that, instead of pursuing a circle of disadvantaged youth living in a cluster of much neglected social housing highrises, who are caught up in insidious cycles of drug running and drug abuse, by following the money instead, they will get to the power and thereby uncover those driving death and destruction into the community.

When I enunciate the imperative of the title of this essay, 'Follow the material!', it's with a similar sense of urgency registered on local and global scales concerning the havoc we are wreaking amidst our collective environment-worlds'. To follow the material can mean to follow a path of environmental devastation, where the best of intentions associated with some new material product turns out to create toxic environments and illness in local populations. For the architect and designer,
In der amerikanischen Fernsehserie The Wire gibt es eine vielsagende Szene, in der ein weiser alter Newcomer in einem Team von Polizeiermittler*innen der Gruppe in mühevoller Kleinarbeit erklärt, dass sie, um dem Drogenring von Baltimore auf den Grund zu gehen, „dem Geld folgen" müssten. Er erklärt seinen Kollegen*innen, deren Versuche, den zerstörerischen lokalen Drogenhandel zu zerschlagen, größtenteils erfolglos geblieben sind: „Wenn man den Drogen folgt, bekommt man Drogensüchtige und Drogendealer, aber wenn man beginnt, dem Geld zu folgen, weiß man verdammt nochmal nicht, wohin es einen führen wird ..." Diese Neuausrichtung ihrer Bemühungen erweist sich als Durchbruch für das Team. Mit der Zeit erkennen die Ermittler*innen, dass es nicht sehr sinnvoll ist, eine Gruppe benachteiligter Jugendlicher zu verfolgen, die in heruntergekommenen Sozialbauten leben und in heimtückische Kreisläufe von Drogenhandel und Drogenmissbrauch verstrickt sind. Stattdessen ist es weitaus zielführender, dem Geld zu folgen und so an jene zu gelangen, die im Hintergrund die Fäden ziehen und Tod und Zerstörung in die Community bringen.

Wenn ich den Imperativ des Titels dieses Essays, „Folge dem Material!", ausspreche, so geschieht dies mit einem ähnlichen Gefühl der Dringlichkeit, wie es auf lokaler sowie globaler Ebene spürbar wird und das die Verwüstungen, die wir in unserer gemeinsamen ,Um-Welt'1 anrichten, 
to follow the material is an exercise in learn-ing what materials can do, as well as understanding the implications of choosing one material over another. To follow the material requires breaking with bad hylomorphic habits, specifically, breaking with the assumption that form or lofty ideas should take precedence over material distribution, and that matter is merely that stuff we use to fill in the abstract shapes of our conceptual design experiments. Too often, material is the after-effect, how we, as designers, color in the spaces between the lines. This is dangerous and irresponsible.

To follow the material is inherently an ethical decision. The act of following demands an ethical comportment toward the world, from within the thick midst of our relational architectural ecologies ${ }^{2}$. As I explain in How to Make Yourself a Feminist Design Power Tool, ${ }^{3}$ in the final chapter, which is dedicated to the imperative, 'Follow the material!', following the materials of your local environment-world means undertaking immanent ethical action. It's about developing a virtuosity in your ethical performances. ${ }^{4}$ Practicing, over and over again, the best approach; thinking on your feet from the midst of your troubles. An important distinction emerges here, espoused by thinkers such as Francesco Varela and Gilles Deleuze, and found between prescriptive principles secured from a moral high ground, which presumes that the thinker is objective, if not omniscient, and ethical know-how that is practiced via trial and error and stays close to the ground, following the rumbling of things. The latter is an active and engaged form of ethics, and far more difficult to pursue. As J.K. Gibson Graham asked, "What can we learn from things that are happening on the ground?"5 betrifft. Dem Material zu folgen kann bedeuten, einem Pfad der Umweltzerstörung zu folgen, wo sich die besten Absichten, die mit einem neuen Werkstoff verbunden sind, als toxische Umgebungen herausstellen und Krankheiten in der lokalen Bevölkerung verursachen. Für Architekt*innen und Designer*innen ist dem Material zu folgen eine Übung, um zu verstehen, was Materialien bewirken können und was es bedeuten kann, ein bestimmtes Material einem anderen vorzuziehen. Dem Material zu folgen bedeutet, mit schlechten hylomorphen Gewohnheiten zu brechen, insbesondere mit der Annahme, dass die Form oder hehre Ideen Vorrang vor der Materialverteilung haben sollten und dass Materie lediglich der Stoff sei, mit dem wir die abstrakten Formen unserer konzeptionellen DesignExperimente ausfüllen. Zu oft ist das Material nur ein Nebeneffekt, wenn wir als Designer*innen die Räume zwischen den Linien ausmalen. Das ist gefährlich und verantwortungslos.

Dem Material zu folgen ist im Wesentlichen eine ethische Entscheidung. Der Akt des Folgens erfordert ethisches Verhalten gegenüber der Welt, aus der dichten Mitte unserer relationalen architektonischen Ökologien heraus. ${ }^{2}$ Wie ich im letzten Kapitel in How to Make Yourself a Feminist Design Power Tool, ${ }^{3}$ das dem Imperativ ,Folge dem Material!' gewidmet ist, erkläre, ist es eine immanent ethische Handlung, den Werkstoffen der lokalen ,Um-Welt' zu folgen. Es geht darum, eine Virtuosität im ethischen Handeln ${ }^{4}$ zu entwickeln. Deshalb heißt es, immer und immer wieder die beste Herangehensweise zu üben; schnell aus der Mitte unserer Probleme heraus zu reagieren! Hier zeigt sich eine wichtige Unterscheidung, wie sie von Denkern wie Francisco Varela und Gilles Deleuze gemacht wird, und zwar zwischen präskriptiven Prinzipien, die 


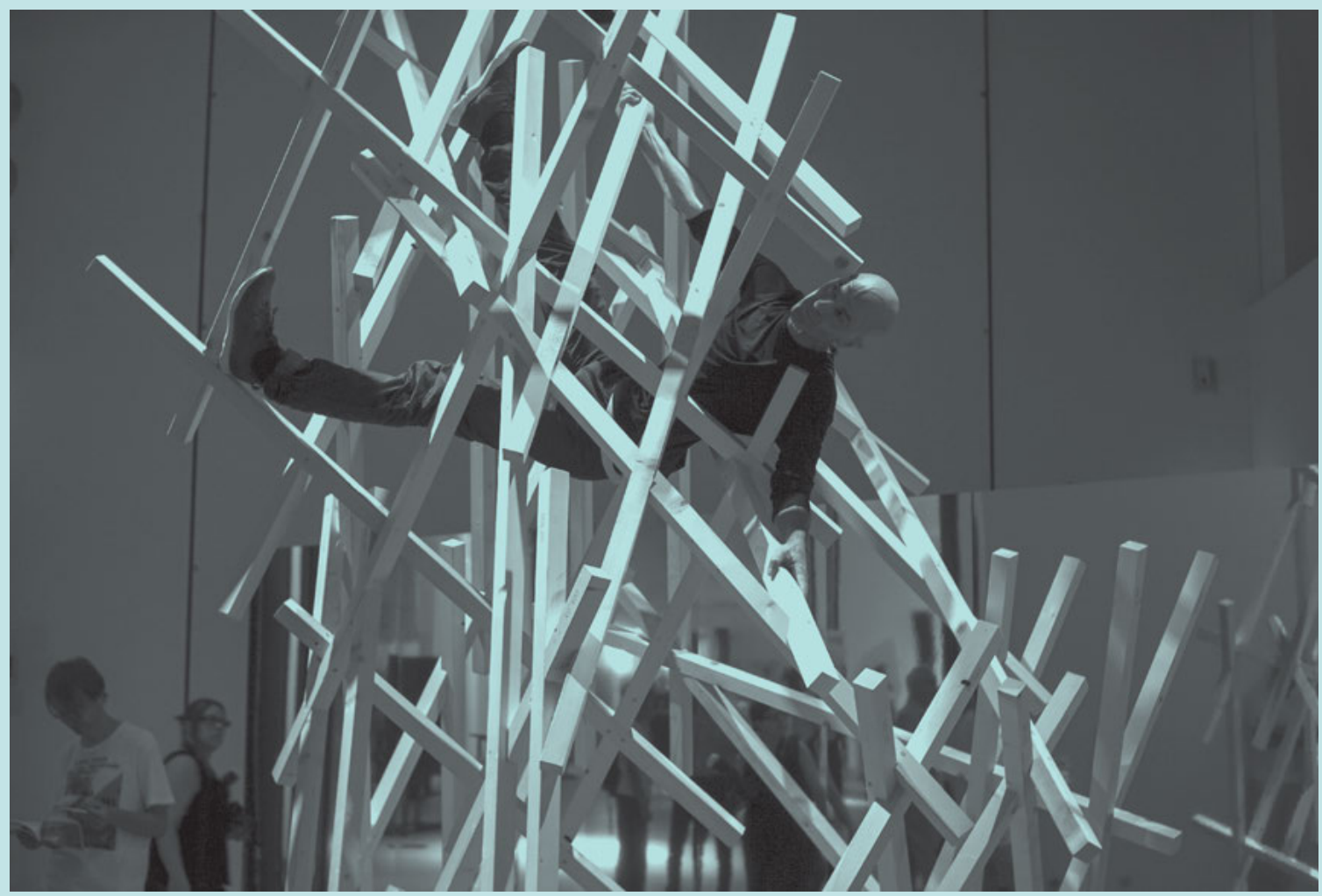

\ Performance artist Daniel Aschwanden interacting with the first Kigumi structure during the exhibition Understanding Art and Research at the Museum of Applied Arts in Vienna (MAK), 2019.

Photo @ Leonard Kern
Staying close to the ground means being prepared to get dirty, or rather, it requires acknowledging that we are already culpable, that we have already made material mistakes that now require mending and amendments. We have to strive to do our work better next time, to develop an ethico-aesthetic know-how.

For me, "Follow the material!", a call formulated as an imperative and therefore projected with urgency, comes most directly from my reading of the work of Gilles Deleuze and Félix Guattari, both when they write individually and in collaboration.

Given that this present collection, Conceptual Joining, focuses on wood as a material for experimentation, it is serendipitous that Deleuze and Guattari use wood as a material example when they discuss what it means, for them, to follow the material. They explain that wood "is more or von einer moralischen Überlegenheit ausgehen, was eine objektive, wenn nicht gar allwissende Denker*in voraussetzt, und ethischem Know-how, das durch ,Versuch und Irrtum' entsteht, indem es dem unbequemen Lauf der Dinge folgt und damit stets auf dem Boden der Tatsachen bleibt. Letzteres ist eine aktive und engagierte Form der Ethik, die weitaus schwieriger umzusetzen ist. Es gilt, wie J. K. Gibson-Graham zu fragen: "Was können wir von den Dingen lernen, die auf dem Boden geschehen?" Nahe am Boden zu bleiben bedeutet, bereit zu sein, sich schmutzig zu machen, oder besser gesagt, es erfordert die Anerkennung, dass wir bereits schuldig sind, dass wir bereits wesentliche Fehler gemacht haben, die nun korrigiert und geändert werden müssen. Wir müssen uns bemühen, unsere Arbeit beim nächsten Mal besser zu machen, ein ethisch-ästhetisches Know-how zu entwickeln. 
less porous, more or less elastic and resistant. At any rate, it is a question of surrendering to the wood, then following where it leads by connecting operations to a materiality, instead of imposing a form upon a matter." This is their anti-hylomorphic recommendation: Don't impose a form, instead, surrender to the wood. Follow it closely to see what it needs, what it can do, and follow it closely to see what it connects to. In addition: "Do not assume a fixed form and a matter deemed homogenous." 7 They speak, for instance, of the "variable undulations and torsions of the fibers guiding the operation of splitting wood." 8 Wood's capacity for deformation, they explain, must be cross-referenced with its more essential qualities, for instance, its porosity, elasticity and resistance, to which might be added whether the wood is a soft or a hard wood. The wood has "material traits of expression", these are the wood's own properties, which means it is capable of some behaviors and not capable of others. All these capacities, or what Deleuze and Guattari also call 'affects', must be understood intimately so that the one working the wood can form the best possible working relationship with the wood.

Matter is subject to continuous variation, it persists for as long as its duration allows amidst a perpetual flux of environmental encounters, performing according to its capacities and affects. Deleuze and Guattari spell out the consequence of understanding matter as flux and flow by insisting that "this matter-flow can only be followed."10 'Following' can be undertaken while staying in place, much as the craftsperson follows the wood while stationed at her work table, but of course, it is also necessary to venture into the woods to source the right kind of wood with the right
Für mich ergibt sich „Folge dem Material!", ein als Imperativ formulierter und daher mit Dringlichkeit versehender Aufruf, am direktesten aus der Lektüre der Arbeiten von Gilles Deleuze und Félix Guattari, sowohl aus ihren individuellen als auch ihren gemeinsamen Schriften.

In Anbetracht der Tatsache, dass die vorliegende Publikation, Conceptual Joining, Holz als experimentelles Material in den Mittelpunkt stellt, ist es ein glücklicher Zufall, dass Deleuze und Guattari Holz als Materialbeispiel verwenden, wenn sie darüber diskutieren, was es für sie bedeutet, dem Material zu folgen. Sie erklären, dass $\mathrm{Hol}$ „mehr oder weniger porös, mehr oder weniger elastisch und widerstandsfähig ist. Auf jeden Fall geht es darum, sich dem Holz hinzugeben und ihm zu folgen, wohin es führt, wenn man Arbeitsabläufe mit einer Materialität verbindet, anstatt der Materie eine Form aufzuzwingen." ${ }^{\text {"t }}$ Ihre anti-hylomorphe Empfehlung lautet: Zwingt dem Holz keine Form auf, gebt euch ihm vielmehr hin. Beobachtet es genau, um zu sehen, was es braucht, was es kann und womit es sich verbindet. Dazu kommt: "Geht nicht von einer festen Form und einer als homogen befundenen Materie aus." ${ }^{17}$ Sie sprechen beispielsweise von den "variablen Wellen und Verdrehungen der Fasern, die den Vorgang des Holzspaltens bestimmen". 8 Die Verformungsfähigkeit des Holzes, so erklären sie, muss mit seinen wesentlicheren Eigenschaften in Beziehung gesetzt werden, zum Beispiel mit seiner Porosität, Elastizität und Widerstandsfähigkeit, zu denen noch hinzukommen könnte, ob es sich um Weich- oder Hartholz handelt. Holz verfügt über "materielle Ausdrucksmerkmale". . Dies sind alles Eigenschaften, die dem Holz eigen sind, was bedeutet, dass es von sich aus zu bestimmten Verhaltensweisen fähig ist und zu anderen nicht. 
kind of fibers. The craftsperson, the designer, must venture out of the safe circle of her studio and venture further afield to gain material knowledge and know-how. Deleuze and Guattari acknowledge that merchants might also bring the material to the craftsperson, but this immediately proves problematic, for how can the craftsperson really know the material if they have not undertaken their own journey into the environment-world of the woods? The moment a merchant or a middleman intercedes, there are further opportunities for a whole chain of actors to line up, one after the other, collecting profits along the way as the wood makes its supply-chain passage from the forest to the worktable.

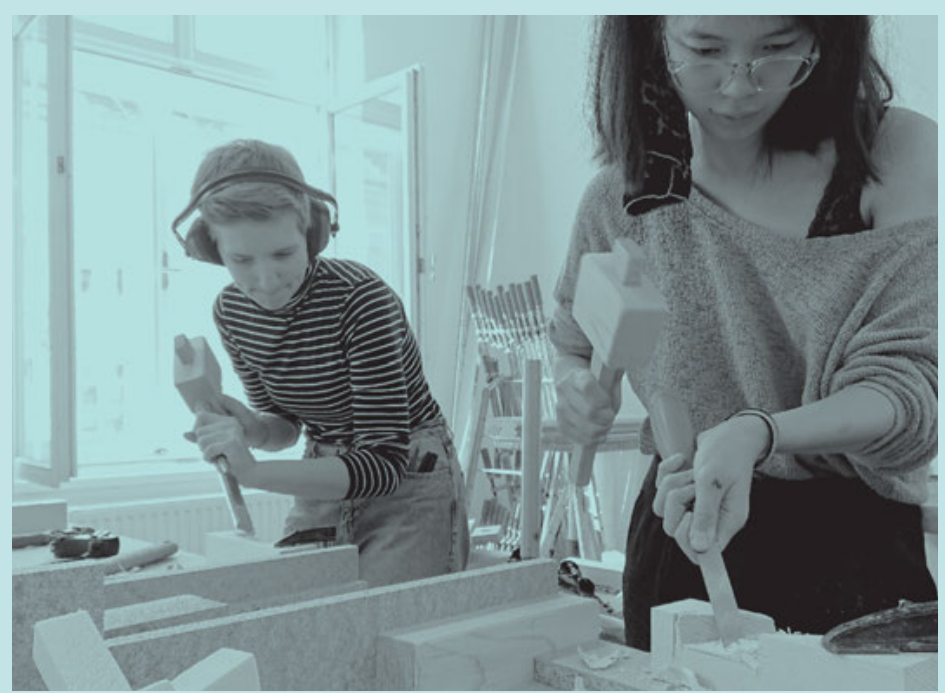

$\Delta$ Students hand-carving joints during the Kigumi workshop with Jun Sato at the Angewandte, 2018.
Now, what is interesting about Deleuze and Guattari's small scene involving a carpenter applying her skills, following the grain of the wood, understanding the disruptive power of the knots, and so forth, is that the larger, more complex supply chains in which she is situated are only hinted at, entering the scene when the merchant arrives with their wares. Questions that emerge when following the ethical imperative 'Follow the material!' include: What wood has
All diese Fähigkeiten - von Deleuze und Guattari auch ,Affekte' genannt - müssen genau verstanden werden, damit die Bearbeiter*innen die bestmögliche Arbeitsbeziehung mit dem Holz eingehen können.

Materie unterliegt kontinuierlicher Veränderung. Sie besteht so lange, wie es ihre Lebensdauer erlaubt, inmitten eines immerwährenden Flusses an Begegnungen mit der Umwelt, und sie verhält sich entsprechend ihren Fähigkeiten und Affekten. Deleuze und Guattari weisen auf die Konsequenz des Verständnisses von Materie als Fluss und Strömung hin, indem sie darauf bestehen, dass "diesem Fluss der Materie nur gefolgt werden kann".10 Folgen kann man auch, wenn man an Ort und Stelle bleibt, so wie die Handwerker*in dem Holz folgt, während sie an ihrem Arbeitstisch steht. Aber natürlich ist es auch notwendig, sich in den Wald zu begeben, um die richtige Art von Holz mit der richtigen Faser-Struktur zu finden. Die Handwerker*in, die Designer*in muss sich aus dem sicheren Terrain ihres Ateliers herauswagen und in die Ferne schweifen, um Materialwissen und Know-how zu erlangen. Deleuze und Guattari räumen ein, dass auch Händler*innen das Material zu den Handwerker*innen bringen könnten. Aber das erweist sich schnell als problematisch, denn wie können Handwerker*innen das Material wirklich kennen, wenn sie nicht eigens in die ,Um-Welt' des Waldes gereist sind? Sobald Händler oder Mittelsmänner ins Spiel kommen, ergeben sich weitere Möglichkeiten für eine ganze Kette von Akteuren, die sich entlang der Lieferkette aneinanderreihen und auf dem Weg des Holzes vom Wald bis zum Arbeitstisch Gewinne einstreichen.

An der kleinen Szene von Deleuze und Guattari, in der eine Tischler*in 
the carpenter chosen to work with? Where did it come from? What global journeys has it already undertaken before it arrived on my work bench? Who has been affected on this journey? What labouring bodies have been made more vulnerable?"11

Jane Hutton's recent book Reciprocal Landscapes: Stories of Material Movements ${ }^{12}$ draws acute attention to the flows of harvested timber, of fering as an example timber chosen for the famous Highline project in New York. While wood is not a dominant material in this project, Hutton explains that it is applied to soften and domesticate the industrial transformation of the former elevated inner city rail line into a public park. The wood used for the original work on the Highline was tropical ipe, which led to protests by the Rainforest of New York group agitating about the unsustainable harvesting of this timber, and the associated "ecological and human rights issues and abuses." 13

Hutton herself 'follows the material' that is ipe by journeying back along its supply chain into the Amazonian forest itself, where she meets members of the Instituto Floresta Tropical (IFT) based in Bélem, Brazil. This is the town, something of a timber gateway to the world, where Timber Holdings is to be found, the exporter that supplied the timber for the Highline project. Rather than painting the picture black and white, Hutton follows the efforts of the IFT to undertake sustainable harvesting by following best practices and attending to licensing rules in order to do this work legally. Still, with the global demand for hard woods, which prove to be hardy materials for domestic garden decking and furniture and public parks such as the Highline, the frontline of logging pushes ever deeper into the Amazon, ihre Fähigkeiten einsetzt, der Maserung des Holzes folgt, die disruptive Kraft der Äste versteht und so weiter, ist interessant, dass die größeren, komplexeren Lieferketten, von denen sie ein Teil ist, nur angedeutet werden und in die Szene Eingang finden, wenn Händler*innen mit ihren Waren eintreffen. Zu den Fragen, die sich ergeben, wenn man dem ethischen Imperativ "Folge dem Material!" folgt, zählen: Welches Holz hat die Tischler*in für ihre Arbeit gewählt? Woher kommt es? Welche globalen Reisen hat es bereits hinter sich, wenn es auf der Werkbank landet? Wer ist von den Auswirkungen dieser Reise betroffen? Welche Arbeiter*innen wurden dadurch noch verwundbarer gemacht? ${ }^{11}$

In ihrem kürzlich erschienenen Buch Reciprocal Landscapes: Stories of Material Movements ${ }^{12}$ weist Jane Hutton auf die Liefer-Ströme von Bauholz hin und nennt als Beispiel das berühmte High-Line-Projekt in New York. Hutton erklärt, dass, obwohl Holz in diesem Projekt eine untergeordnete Rolle spielt, es eingesetzt wird, um das industrielle Areal im Zuge seiner Transformation von einer ehemaligen innerstädtischen Hochbahnlinie in einen öffentlichen Park abzumildern und zu domestizieren. Zu Beginn des Baus des High-Line-Projektes wurde tropisches Ipe verwendet, was zu Protesten der Gruppe Rainforest of New York führte, die die nicht-nachhaltige Ernte dieses Holzes und die damit verbundenen „ökologischen und menschenrechtlichen Probleme und Missstände"13 anprangerte.

Hutton selbst, folgt dem Material' lpe, indem sie entlang seiner Lieferkette zurück in den Amazonaswald reist und dort die Mitglieder des Instituto Floresta Tropical (IFT) an ihrem Standort in Bélem in Brasilien trifft. In dieser Stadt, die als Tor zur Welt des Holzes bezeichnet werden kann, befindet sich 


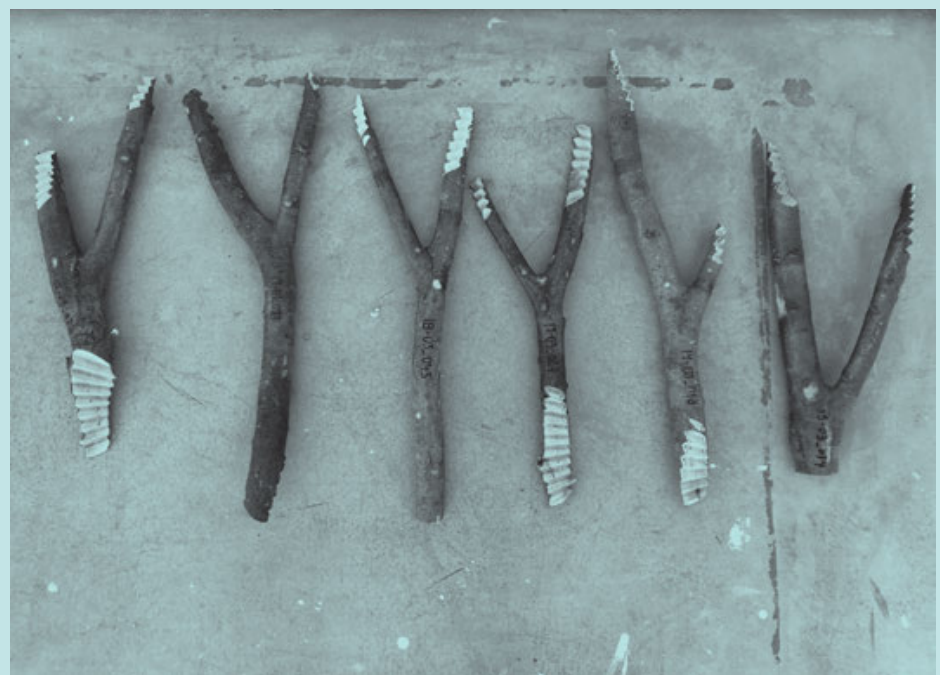

$\Delta$ CNC-processed hornbeam and beechwood branch parts prior to assembly, at the Angewandte Innovation Laboratory (AIL), 2019.

Timber Holdings, die Exportfirma, die das Holz für das High-Line-Projekt geliefert hat. Anstatt das Bild schwarzweiß zu malen, verfolgt Hutton die Bemühungen des IFT nach, wie es versucht, eine legale und nachhaltige Holzernte durchzuführen, indem es Best Practices befolgt und sich an Lizenzregeln hält. Doch mit der weltweiten Nachfrage nach Harthölzern, die sich als widerstandsfähiges Material für heimische Gartenterrassen und -möbel sowie öffentliche Parks wie das High-Line-Projekt erwiesen haben, dringt die Front der Abholzung Schritt für Schritt immer tiefer in den Amazonas vor und nimmt dabei langsam dem gesamten Planeten immer mehr die Fähigkeit zu atmen.

step by slow step, reducing the capacity of the whole earth system to breathe.

To follow the material means to pay attention. What does the wood want to do? ${ }^{14}$ By paying attention and responding to the specific implications of such questions, how might the designer respond in the most ethical way? Paying attention to the many goddesses in the details may well lead us to better worlds, and to more amenable, less destructive, environmental relations. To follow the material could be part of the journey made from the design detail to utopia, but it's more likely that following the material will mean 'staying with the trouble.' This is the slogan that Donna Haraway, provocative thinker of science and technology, has called out loud and clear in her more recent work. ${ }^{15}$ You see, the risk of thinking towards Utopia, which is by definition nowhere - not here, not now - is that we are holding out for that promised day, and forgetting to act right here, from the mess of the now, from the dirt and grime and difficulty of our immediate, immanent milieu.
Dem Material zu folgen bedeutet, aufmerksam zu sein. Was möchte das Holz tun? ${ }^{14}$ Wie könnte die Designer*in am ethischsten agieren, wenn sie auf die spezifischen Implikationen solcher Fragen achtet und darauf eingeht? Wenn wir den vielen, Göttinnen der kleinen Dinge' Rechnung tragen, kann dies durchaus zu einer besseren Welt führen und unsere Umweltbeziehungen verträglicher und weniger zerstörerisch machen. Dem Material zu folgen könnte ein Teil der Reise sein, die vom Design-Detail zur Utopie führt. Wahrscheinlicher ist es jedoch, dass dem Material zu folgen bedeutet: „unruhig bleiben”. Das ist die Parole, die Donna Haraway, provokante Denkerin im Bereich Wissenschaft und Technologie, in ihren rezenten Werken laut und deutlich ausruft. ${ }^{15}$ Man sieht, das Risiko des Denkens in Richtung Utopie, die per definitionem nirgendwo ist - nicht hier, nicht jetzt -, liegt darin, dass wir auf diesen versprochenen Tag warten und vergessen, genau hier zu handeln, aus dem Chaos des Jetzt heraus, aus dem Schmutz und Elend und den Schwierigkeiten unseres unmittelbaren, immanenten Umfeldes heraus. 


\section{ADDITIONAL REFERENCES I WEITERE REFERENZEN:}

Alaimo, S., Hekman, S. (eds.) (2009): Material Feminisms, Bloomington: Indiana University Press.

Coole, D., Frost, S. (eds.) (2010): New Materialisms: Ontology, Agency, and Politics., Durham, NC: Duke University Press.

Deleuze, G. (1988): Spinoza: Practical Philosophy, trans. Robert Hurley, San Francisco: City Lights.

Dolphijn, R., van der Tuin, I. (eds.) (2012): New Materialism: Interviews and Cartographies, Ann Arbor, MI: Open Humanities Press, University of Michigan Library.

Frichot, H. (2019): Dirty Theory: Troubling Architecture, Baunach: Spurbuchverlag.

Lloyd Thomas, K. (ed.) (2007): Material Matters: Architecture and Material Practice, London: Routledge.

1 en see Frichot, H. (2016): How to Make Yourself a Feminist Design Power Tool, Baunach: Spurbuchverlag: 88: "I take the conjunction environment-world from the idiosynchratic work of Uexküll who uses the term Umwelt: a surrounding, engulfing world. (Uexküll, 2010) [...] Environment-world is my own 'bad' translation of the German term Umwelt, which would usually be translated as, quite simply, 'environment'. The thing is, that the German can also be taken at face value, literally. As such we have two parts - um and Welt - the first meaning 'surroundings', or that which surrounds, and the second meaning 'world'." de siehe dazu Frichot, H. (2016): How to Make Yourself a Feminist Design Power Tool, Baunach: Spurbuchverlag: 88: „Die Konjunktion environment-world entnehme ich der ideosynkratischen Arbeit von Uexküll, der den Begriff Umwelt verwendet als: eine umgebende, verschlingende Welt. (Uexküll, 2010) [...] Environment-world ist meine eigene, schlechte' Übersetzung des deutschen Begriffs, Umwelt', der normalerweise ganz einfach mit ,environment' übersetzt wird. Die Sache ist die, dass das Deutsche auch wörtlich genommen werden kann. Wir haben also zwei Teile - um und Welt -, wobei das erste ,Umgebung' oder das, was umgibt, und das zweite ,Welt' bedeutet."

2 Rawes, P. (ed.) (2013): Relational Architectural Ecologies, London: Routledge.

3 Frichot, H. (2016): How to Make Yourself a Feminist Design Power Tool, Baunach: Spurbuchverlag.

4 Varela, F. J. (1999): Ethical Know-How: Action, Wisdom and Cognition, Stanford, CA: Stanford University Press.

5 Gibson-Graham, J. K. (2011): "A Feminist Project of Belonging for the Anthropocene", in: Gender, Place \& Culture, 18(1): 1-21, here: 4.

6 Deleuze, G., Guattari, F. (1987): A Thousand Plateaus: Capitalism and Schizophrenia, trans. Brian Massumi, Minneapolis: University of Minnesota Press. 408; see also Frichot 2016.

7 Deleuze, Guattari 1987: 408.

8 ibid.

9 ibid.

10 ibid, 409

11 see Borasi, G. (2010): Journeys: How Travelling Fruit, Ideas and Buildings Rearrange Our Environment, Montreal: CCA, and Barcelona: Actar.

12 Hutton, J. (2020): Reciprocal Landscapes: Stories of Material Movements, London: Routledge.

13 ibid, 209

14 see Lefebvre, P. (2018): "What the Wood wants to do': Pragmatist Speculations on a Response-able Architectural Practice", in: Doucet, I., Frichot, H. (eds.) (2018): Resist, Reclaim, Speculate: Situated Perspectives on Architecture and the City, special edition, Architectural Theory Review, 22(1): 24-41.

15 en Haraway, D. (2016): Staying with the Trouble: Making Kin in the Chthulucene, Durham: Duke University Press.

de Haraway, D. (2018): Unruhig bleiben: Die Verwandtschaft der Arten im Chthuluzän, Frankfurt am Main: Campus. 
